\title{
Information-seeking behaviour of security studies students: A case study
}

\begin{tabular}{|c|c|}
\hline $\begin{array}{l}\text { Authors: } \\
\text { Theodora Thir } \\
\text { Winner D. Cha } \\
\text { Gift Dube }^{3} \text { (1) }\end{array}$ & dwa $^{1}$ (D) \\
\hline $\begin{array}{l}\text { Affiliations: } \\
{ }^{1} \text { Department } \\
\text { Peace and Sec } \\
\text { Mzuzu Univer } \\
\text { Malawi }\end{array}$ & $\begin{array}{l}\text { f Governance, } \\
\text { urity Studies, } \\
\text { sity, Mzuzu City, }\end{array}$ \\
\hline $\begin{array}{l}{ }^{2} \text { Department } \\
\text { Sciences, Mzu } \\
\text { Mzuzu City, M }\end{array}$ & $\begin{array}{l}\text { f Information } \\
\text { zu University, } \\
\text { alawi }\end{array}$ \\
\hline $\begin{array}{l}{ }^{3} \text { Library and L } \\
\text { Resources Cer } \\
\text { University, Mz } \\
\text { Malawi }\end{array}$ & $\begin{array}{l}\text { earning } \\
\text { tre, Mzuzu } \\
\text { uzu City, }\end{array}$ \\
\hline $\begin{array}{l}\text { Correspondin } \\
\text { Winner Chaw } \\
\text { winnchawinga }\end{array}$ & $\begin{array}{l}\text { g author: } \\
\text { nga, } \\
\text { @gmail.com }\end{array}$ \\
\hline $\begin{array}{l}\text { Dates: } \\
\text { Received: } 24 \\
\text { Accepted: } 08 \\
\text { Published: } 30\end{array}$ & $\begin{array}{l}\text { ct. } 2018 \\
\text { Mar. } 2019 \\
\text { May } 2019\end{array}$ \\
\hline $\begin{array}{l}\text { How to cite th } \\
\text { Thindwa, T., C } \\
\text { Dube, G., 2015 } \\
\text { seeking behav } \\
\text { studies studen } \\
\text { study', South } \\
\text { of Information } \\
21(1) \text {, a1048. I } \\
\text { 10.4102/sajim }\end{array}$ & $\begin{array}{l}\text { is article: } \\
\text { hawinga, W.D. \& } \\
\text {, 'Information- } \\
\text { iour of security } \\
\text { ts: A case } \\
\text { frican Journal } \\
\text { Management } \\
\text { ttps://doi.org/ } \\
\text { v21i1.1048 }\end{array}$ \\
\hline $\begin{array}{l}\text { Copyright: } \\
\text { (c) 2019. The } \\
\text { Licensee: AOS } \\
\text { is licensed un } \\
\text { Creative Comr } \\
\text { Attribution Lic }\end{array}$ & $\begin{array}{l}\text { uthors. } \\
\text { S. This work } \\
\text { ler the } \\
\text { nons } \\
\text { ense. }\end{array}$ \\
\hline Read online: & \\
\hline 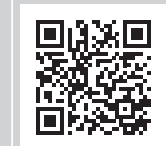 & $\begin{array}{l}\text { Scan this QR } \\
\text { code with your } \\
\text { smart phone or } \\
\text { mobile device } \\
\text { to read online. }\end{array}$ \\
\hline
\end{tabular}

Background: Undergraduate students need information for various reasons. However, it is not a straightforward activity in retrieving the relevant information for accomplishing various needs. This research is therefore justified as it aims at understanding information needs of undergraduate students who are drawn from security organisations.

Objectives: The main objective of this study was to analyse information needs, sources and seeking patterns of security studies at Mzuzu University.

Method: The study adopted a mixed methods approach by sending a questionnaire to 108 students and conducting a set of three focus group discussions. The study was informed by Kuhlthau's information search process model.

Results: The study finds that most students preferred Internet as a source of information. The study further finds that most students need information mainly for academic activities, accomplishing assignments, preparing examinations and completing research projects. Most students preferred the search engines as the starting point for an information search. Feelings proposed by Kuhlthau's information search process model, which include anxiety, optimism, uncertainty and excitement, were experienced by most of the students as they started an information search for completing an assignment. However, there exist a number of challenges that affect students' information behaviour, such as the lack of online information literacy skills, poor Internet access and shortage of computer laboratories.

Conclusion: Unlike previous studies, this study establishes that the information needs of upgrading security studies students are focussed more on academic and work-related purposes. Information seeking and gathering is a key component of their work, as they gather information related to criminal activities and general intelligence. Upgrading undergraduate students have additional information needs that go beyond their academic needs. There is a need to design information interventions that would enhance their information search experience based on some of the pointers provided by Kuhlthau's model. In view of the above, it can be argued that Internet is becoming a popular source of information in the 21st century; hence, there is a need to provide e-support that would reduce students' negative feelings and enhance their Internet search process, thereby improving the overall quality of education.

Keywords: Security studies; information needs; Kuhlthau's information search process model; information seeking; Internet.

\section{Introduction}

The ability of individuals to acquire information whether for personal or academic purposes has been of paramount importance (Ferran-Ferrer, Minguillion \& Perez 2013; Sookhtanlo, Mohammadi \& Rezvanfar 2009). In order to facilitate the availability of information to targeted users, information providers over the years have come up with information structures known as information systems. These information systems provide structures of data and information organisation in print and electronic forms to help information access (Ikoja-Odango \& Mostert 2006). Previously, the major concern was how information seekers used information systems rather than needs and behaviour that individuals displayed when interacting with the systems (Wilson 2000).

However, there has been a paradigm shift from studying information systems to informationseeking behaviour. For example, in the middle of the 20th century, the Royal Society Scientific Information Conference (1948) gave birth to the modern study of human information behaviours in the process of seeking information. The conference expressed the need for scientific researchers to understand how people use information in relation to their work (Wilson 2000). In the 1960s, library 
information researchers extended the concept of informationseeking behaviour to other professions (Guclu \& Can 2015). Information behaviours involve the identification of an information needs, seeking information to satisfy the needs and information-seeking behaviours that are manifested during the process of information seeking and use, and channels used in the process of information seeking (Ferran-Ferrer et al. 2013; Kuhlthau 1993; Shyu \& Pern 2013). Wilson's 1999 model of information behaviour explains that information-seeking behaviour is a subset of information behaviour and information search is a subset of informationseeking behaviour (Adio \& Arinola 2012). Ikoja-Odongo and Mostert (2006) add that information-seeking behaviour as a subset of information behaviour involves understanding of how people seek information and use it, what channels they use to find information and what the factors are that encourage and discourage the use of information. Individuals perform specific actions in order to satisfy their information needs (Savolainen 2007; Tella 2009).

Studies in information behaviour and information seeking help in identifying information needs, understanding of factors that influence the use of information and challenges that users face when seeking information, thereby helping to design good information services (Adio \& Arinola 2012; Khalil-Maliki \& Azhar 2011; Singhi \& Rani 2013; Whitmire 2001). In addition, studies in information-seeking behaviour help information providers to come up with appropriate information systems that may enhance information access for different groups of users for improved performance (Ferran-Ferrer et al. 2013; Ikoja-Odongo \& Mostert 2006). For, example, in the security domain, understanding the information-seeking seeking behaviour of police officers has the potential to enhance security through the provision of the information environment that responds to their security needs (Guclu \& Can 2015).

Undergraduate students have different information needs and they display different information behaviours when searching information to satisfy their needs. These information behaviours are influenced by different factors (Nwobasi, Uwa \& Ossai-Onah 2013). Mizrachi and Bates (2013) state that:

\footnotetext{
... different information styles may be more of a result of cognitive and affective differences and students have individualist approach to their information behaviours ... driven by accessibility, urgency and work flow factors ... [and also] ... affected by individual personalities and affections as well as by time pressures and constrains. (p. 1605)
}

More so, literature shows that undergraduate students have different information needs, display different information behaviour and encounter various challenges when meeting their needs because of different reasons (Baro, Onyenania \& Osaheni 2010; Chaura 2014; Karas \& Green 2007; Saad \& Zainab 2009; Sookhtanlo, Mohammadi \& Rezvanfar 2009). It is for the aforementioned reasons that a study was conducted to understand the information-seeking behaviour of a unique group of students (security studies) in Malawi. This was done in spite of numerous studies that have been conducted to demystify the information-seeking behaviours of students in different countries and fields of studies (Baro et al. 2010; Chaura 2014; Karas \& Green 2007; Saad \& Zainab 2009; Sookhtanlo et al. 2009).

\section{Problem statement}

The problem of this study arises from two scenarios. Firstly, one of the researchers who is also a lecturer in the Centre for Security Studies has on several occasions noted students' confusion each time they are given an assignment. For instance, despite being provided with a list of recommended and prescribed texts (information sources) for the course, and the assignments in particular, students still come back to the lecturers to seek further clarifications and advice on how to find suitable information. In addition, students have pointed out that there is usually very little information on security issues on the Internet because security issues are considered to be sensitive. Secondly, the other two researchers who are qualified library professionals and lecturers in the Department of Library and Information Science at Mzuzu University have noted that some students seem to be more confused when using information resources in the library and from other sources such as the Internet. The students usually flood the Readers Service Librarian Office seeking help on issues related to information seeking. It is against this backdrop that this study was conducted to demystify the informationseeking behaviour of undergraduate students, with security studies as a case study. Despite preliminary literature showing that a study on information behaviour was conducted by Chaura (2014) at Mzuzu University, this study differs from that of Chaura (2014) in that he investigated the information behaviour of all students from all departments and left out students from the Centre of Security Studies, perhaps because it was not within the scope of his study. Several studies show that students have different information needs and display different information-seeking behaviours (Baro et al. 2010; Chaura 2014; Karas \& Green 2007; Saad \& Zainab 2009; Sookhtanlo et al. 2009); hence, there is a need to understand the information-seeking behaviour of security studies students in this study.

In light of the research gap, the study was guided by three research questions as follows:

- What are the information needs of security studies students at Mzuzu University?

- What are the information sources and information seeking patterns of security studies students at Mzuzu University?

- What are the challenges that affect security studies students' access and use of information at Mzuzu University?

\section{Literature review Information needs of students}

Kuhlthau (1993:161) defines information need as any gap between an individual's knowledge about a problem and 
what an individual needs to know in order to effectively solve an existing problem. Students in university need information to meet their academic, professional and personal needs. Therefore, it is certain that an information need is a driving force behind an individual's desire to seek information (Ajiboye \& Tella 2007; Chaura 2014; Kakai, Ikoja-Odongo \& Kigonga-Bukenya 2004). For example, Kakai et al. (2004) reported that students at Makerere University in Uganda needed information to prepare for examinations and tests, to complement lecture notes and to accomplish research projects in order to fulfil their information needs. In a similar study, Ajiboye and Tella (2007) found that university students rated academic information as the most sought-after information, followed by personal development information which was not noted in an earlier study by Kakai et al. (2004).

Furthermore, studies conducted by Oladokun and Aina (2009) on information needs of continuing students at the University of Botswana and Chawinga and Zozie (2016) on information needs of open and distance learners at Mzuzu University, found that students mainly needed information to accomplish their course activities and general educational purposes. For example, students sought information for further studies and sources of scholarship and information for job opportunities. It is noted through literature review that university students, whether full time or distant students, mostly need information to satisfy their academic needs (see Chawinga \& Zozie 2016; Kakai et al. 2004; Nkomo, Ocholla \& Jacobs 2011; Oladokun \& Aina 2009).

\section{Information sources and information- seeking patterns}

An information source is an important component of the concept or process in the domain of information seeking. Previously, a library was the key source of information for most of the university students. However, the Internet has now overtaken the library and is surely proving to be the most used source of information (Vezzosi 2009:69). Other studies have shown that the Internet is the most common source of information for university students in various countries, such as Israel (Greenberg \& Bar-llan 2014), Botswana (Ajiboye \& Tella 2007) and Malawi (Chawinga \& Zozie 2016). However, credible online information sources are rarely consulted by students. For example, Nkomo et al.'s (2011) study revealed a low exploitation of websites or online databases that hosted scholarly materials. In addition to the Internet, other resources include lecture notes, lecturers, colleagues and library resources (Baro et al. 2010; Chawinga \& Zozie 2016; Oladokun \& Aina 2009).

\section{Challenges that affect access and use of information}

The majority of prior research has shown that university students' information-seeking activities and use are affected by several challenges. In their study, Abrahamson and Goodman-Delahunty (2014:9) found that one of the impediments to information sharing within the policing sector in Canada is unwillingness by some officers to share critical information 'due to personal attitudes, values, beliefs, and/or actions'. In addition, students' ability to identify credible sources of information online is another reason. Prior studies, such as the ones by Nkomo et al. (2011) in two South African universities and Karobilli, Malliadri and Zapounidou (2011) in Israel, reveal that students unknowingly used online databases and websites that do not host credible information resources and rarely used scholarly databases or e-journals for their academic activities. Furthermore, Duncan and Holtslander (2012) noted students' inability to formulate keywords as search terms or phrases as an outstanding challenge. Similarly, Bhatti (2008) reported that students usually face difficulties in finding library materials in shelves. Chaura (2014:25) concluded that 'lack of information literacy skills was the reason students fail to find relevant materials to satisfy their information needs'.

\section{Theoretical framework: The information search process model}

Lester (2005:461) argues that theoretical frameworks help researchers to competently answer the why questions which the researcher can simply guess or fail to offer any meaningful explanation to the outcomes of the study. There are many and well-accepted models used to study information-seeking behaviour in various social settings. Information-seeking behaviour models were developed to help researchers understand circumstances that predict actions by individuals seeking information. Some of such notable models include those by Wilson (1981), Krikelas (1983) and Kuhlthau (1993). This study is underpinned by a rather very old but still very relevant model called the information search process (ISP) model, which was propounded by Kuhlthau (1993). The key motivational factor behind the development of the ISP model was an observation by Kuhlthau about high school students' seemingly confusion and anxiety when searching information in the library for accomplishing school assignments in the United States of America (Kuhlthau 1993). This model provides an overview of the information search experience by the user at the cognitive (thoughts), affective (feelings) and physical (actions) levels. According to Byström and Jarvelin (1995:192), as individuals search for information, they experience three realms of activity: physical (action taken), affective (feelings experienced) and cognitive (thoughts about processes and content).

The process of information search is viewed through six stages: task initiation, selection, exploration, focus formulation, collection and presentation (Kuhlthau, Heinström \& Todd 2008). As individuals go through the six stages of ISP, they also experience the cognitive, affective and specific actions that come into play with varying intensities depending on the phase in the information process. For instance, individuals experience feelings of 'uncertainty, frustration and confusion' in the early phases of task initiation. However, as individuals go through the other phases, such as focus formulation, they report feeling confident and convinced of the information gathered. Therefore, the ISP model provides a holistic perspective of the information users (Kundu 2017:399) 


\begin{tabular}{|c|c|c|c|c|c|c|}
\hline Tasks & Intiation & Selection & Exploration & Formulation & Collection & Presentation \\
\hline $\begin{array}{l}\text { Feelings } \\
\text { (Affective) }\end{array}$ & Uncertainty & Optimism & $\begin{array}{l}\text { Confusion frustration } \\
\text { doubt }\end{array}$ & Clarity & $\begin{array}{l}\text { Sense of direction, } \\
\text { confidence }\end{array}$ & $\begin{array}{l}\text { Satisfaction or } \\
\text { disappointment }\end{array}$ \\
\hline \multirow[t]{3}{*}{$\begin{array}{l}\text { Thoughts } \\
\text { (Cognitive) }\end{array}$} & Vague ----- & & $\stackrel{---\rightarrow}{\longrightarrow}$ & & & \\
\hline & & & & Focused & & \\
\hline & & & & \multicolumn{3}{|c|}{ Increased interest } \\
\hline \multirow{2}{*}{$\begin{array}{l}\text { Actions } \\
\text { (Physical) }\end{array}$} & & & & & \multicolumn{2}{|c|}{ Seeking pertinent information } \\
\hline & $\begin{array}{l}\text { Seeking relevant } \\
\text { information }\end{array}$ & & & & \multicolumn{2}{|l|}{ Documenting } \\
\hline
\end{tabular}

Source: Kuhlthau, C., Maniotes, L. \& Caspari, A., 2012, Guided inquiry design: A framework for inquiry in your school, Libraries Unlimited, California FIGURE 1: Summary of the information search process model.

The ISP model was preferred over other existing informationseeking models because of its ability to address all research questions of this study. More importantly, the model has been successfully used by many previous studies to understand the information-seeking behaviour of undergraduate students (Chaura 2014; Hildegard 2006). Kuhlthau et al. (2008:68) concluded that an ISP is a task model of information behaviour that describes how people search information to accomplish a task within a specific period of time. The model espouses that there is always uncertainty when an individual starts the process of searching information and such an uncertainty diminishes as an understanding increases. Figure 1 presents a summary of the ISP model.

\section{Methodology}

In investigating the research questions, we employed a case study method because the contextual nature of the study required that an in-depth examination of the problem should be carried out (Punch 1998:150). Thus, in order to investigate the complex issues surrounding information-seeking behaviour of security studies students, we collected both qualitative and quantitative data, a technique referred to as mixed methods by the research community (Muijs 2010:8).

\section{Target population}

In the study data from security studies students at Mzuzu University were collected. There were only level 1, level 2 and level 3 students when data were collected. Level 4 students had recently finished their studies and thus it was not possible for the researchers to collect data from this group. All students in the three levels were included in the study. The age range of the respondents in this study was 25-40 years. All the students in the centre are referred to as 'upgrading students', meaning that they qualify to join the university by considering their work experience in the security sector in addition to having good grades in the Malawi School Certificate of Education (MSCE). The programme is flexible such as that students could exit or graduate with diplomas at year 2 or with a bachelor's degree at level 4. Most of the students are drawn from state security bodies, such as the Malawi Army, the Malawi Police Service, Malawi Prisons, the Department of Immigration and the National Intelligence Bureau.

\section{Data collection: Questionnaires and focus group discussions}

To collect qualitative and quantitative data, two data collection instruments - a questionnaire and a focus group interview guide - were used. The questionnaire mostly collected quantitative data and it mainly included closedended questions where the respondents were required to tick answers that were applicable to their information-seeking activities. The questionnaire for quantitative data were custom made specifically to solicit necessary information from students from the security sector. Apart from the background information section which had five preliminary questions, the questionnaire had three sections that solicited data on various aspects of students' information-seeking activities. The first section solicited data on the information needs of security studies students' information needs, the second section gathered data on information sources and seeking patterns of security studies students and the final section had a set of questions that collected data on the challenges that security studies students faced in accessing and using information from various sources and formats.

We conducted focus group discussions (FGDs) with students from each of the three classes. FGD 1 (level 1) had six members, FGD 2 (level 2) had five members and FGD 3 (level 3) had six members. While our intention was to record discussions from each group, only FGD 1 members accepted to be recorded, whereas FGD 2 and FGD 3 members did not provide their consent to record the discussions. Thus, we only took notes for FGD 2 and FGD 3. On average, each group session lasted between 38 and $50 \mathrm{~min}$. Although many prior similar studies had used interviews to gather qualitative data, we opted for focus groups for two key reasons. Firstly, focus groups have been heralded 'to be very effective in drawing upon respondents' attitudes, feelings, beliefs, experiences' (Kurniawan, Mahmud \& Nugroho 2006:991). Secondly, focus groups have the ability to encourage participants to collectively reflect more on the topic than what they would do in individual interviews (Morgan 1997) because as participants listen to other members, they tend to reflect on their opinions and beliefs and contribute to the topic with more fresh and better ideas. Focus groups 
questions were guided by the key themes of the study, which included information needs, information seeking and patterns and challenges that affect security studies students' information-seeking behaviour.

\section{Sampling techniques}

A purposive non-probability sampling technique was used to select respondents for the questionnaire because the researchers were targeting security studies students only as rich data sources, given the nature of the research questions of this study. On the other hand, it was not possible to include every participant in the FGD. The respondents were sampled through convenient sampling, were security studies students from the security bodies and were selected based on their availability, willingness to participate and easy access (Etikan, Musa \& Alkassim 2016).

\section{Data analysis}

The Statistical Package for the Social Sciences (SPSS) software was used to analyse quantitative data by producing frequencies and percentages. In our opinion, Microsoft Excel produces more appealing figures and charts than SPSS; hence, some data were exported from SPSS to Microsoft Excel to produce charts and figures that could depict the frequencies and percentages. Qualitative data collected through focus groups were analysed thematically. Thematic analysis is a method for identifying, analysing and reporting patterns (themes) within data (Braun \& Clarke 2006). Data collected through FGDs were also transcribed into a word document. In the present study, thematic analysis was performed through identifying commonly recurring and prevalent themes, which assisted in answering the research questions. Both qualitative and quantitate data were analysed through the lens of the ISP model (Kuhlthau 1993). To arrive at more credible and objective conclusions from the study, we validated (or triangulated) quantitative data collected through questionnaires and qualitative data collected through focus groups.

\section{Ethical consideration}

Ethical clearance was obtained from the Director of Research at Mzuzu University, Malawi.

\section{Results and discussion Information needs of security studies students}

Students were asked to indicate the reasons they need information in their general life affairs. The results showed that most students with a score of $85(98.8 \%)$ need information mainly for accomplishing academic activities, followed by information for career development, which was cited by $54(62.8 \%)$ students, and information for further education after diploma and degree programmes with a score of $46(53.5 \%)$. According to the findings, it is logical to conclude that students mind less about entertainment because only a small number of students with a score of $21(24.4 \%)$ said that they needed information for general purposes, such as entertainment. Findings from the questionnaire are well supported by those from FGDs, as evidenced by a comment from one of the participants from FGD 1, who said: 'we mostly seek information for assignments, and to pass examinations'. The current findings give credence to prior studies that have shown that students need information for academic activities more than for general purposes (Baro et al. 2010; Chaura 2014; Kakai et al. 2004; Nkomo et al. 2011; Oladokun \& Aina 2009). This implies that the security studies students are active information seekers who are fully aware of the purpose of collecting information. Furthermore, there is a manifestation of Kuhlthau's model, sense of direction under the collection phase and also the documentation of pertinent information, as students seem to focus mostly on information for academic purposes (Kuhlthau et al. 2012).

Findings from FGDs also revealed that students need information to accomplish work tasks on security activities, as evidenced in the following comment from one of the three FGDs: 'As a security studies students we need information to follow current affairs that will help us in decision making especially in careers such as intelligence'. This implies that being upgrading students they need information not only for academic purposes but also for their workplace. Information seeking and gathering is a key component of their work as they gather information related to criminal activities and general intelligence. The information gathering is useful for securing lives of individuals, property and also the state. It is clear from the study that much of the work in the security sector relies on information gathering. On the other hand, the focus on information for work purposes is a departure from the literature which argues that undergraduate students focus on academic information (Chawinga \& Zozie 2016; Kakai et al. 2004; Nkomo et al. 2011; Oladokun \& Aina 2009). Therefore, upgrading undergraduate students have additional information needs that go beyond their academic needs. Hence, there is a need to design information interventions that would enhance their information search experience, based on some of the pointers provided by Kuhlthau's model.

Furthermore, results from the questionnaire revealed that a meager number of $22(25.6 \%)$ students needed information for jobs seeking and $32(37.2 \%)$ needed information for scholarship. Those who are self-sponsored students are most likely to look for information on scholarships, while those who are fully sponsored are less likely to do so. This may be attributed to the fact most of the students are already employed by the Malawi government as police officers, intelligence officers, prison officers, immigration officers and army officers and some are sponsored by the same government. Therefore, these students pursue security studies courses at Mzuzu University in order to add more knowledge and skills to improve their work and most likely to go through the ISP model as highlighted by Kuhlthau. Hence, there is the need to include specific interventions that would enhance learning of these students. 
As revealed in the preceding section, 85 (98.8\%) students needed information for academic purposes. In that regard, a follow-up item required students to indicate the types of academic activities that they accomplished using the information they sought. The findings are presented in Figure 2. An analysis of the findings in Figure 2 reveals that most students need information to accomplish assignments, followed by end of semester examinations. Half of the students need information to prepare for mid-term tests. This agrees with our experience as lecturers. A few students need information for mid-term tests because most lecturers at Mzuzu University prefer administering written assignments (either group or individual) to students rather than mid-term tests. A cross-tabulation of the results revealed that most of the respondents who needed information for the research project were in level 3. Results from the FGDs showed that level 3 students needed this information because they were developing their proposals.

\section{Information sources and seeking patterns}

As revealed in the previous sections, most of the students needed information to accomplish various academic activities. We thus asked students to cite places where they seek information from. Results showed that the majority of students with a score of $77(89.5 \%)$ use the Internet as a source of information, followed by friends and lecturers, which had a score of $64(74.4 \%)$ each, and the departmental library with a score of $37(43.0 \%)$. Only $32(37.2 \%)$ students indicated that they seek information from the Mzuzu University Library. Results from the FGDs showed that most of the students did not use the library because it lacked books pertinent to their discipline. This is echoed in the following verbatim: 'some library books are very few, so when you have an assignment and are given $2 \mathrm{~h}$ only, to use the reserve books it is not adequate', and another who agreed said: 'because of the shortage of the books we rely on the Internet'. Prior studies have also showed that students at Mzuzu University prefer Internet as a source of information. These findings are supported by a study on information-seeking behaviour of distance learning students at Mzuzu University by Chawinga and Zozie (2016), which found that 207 (80.5\%) students used the Internet as a source of information.

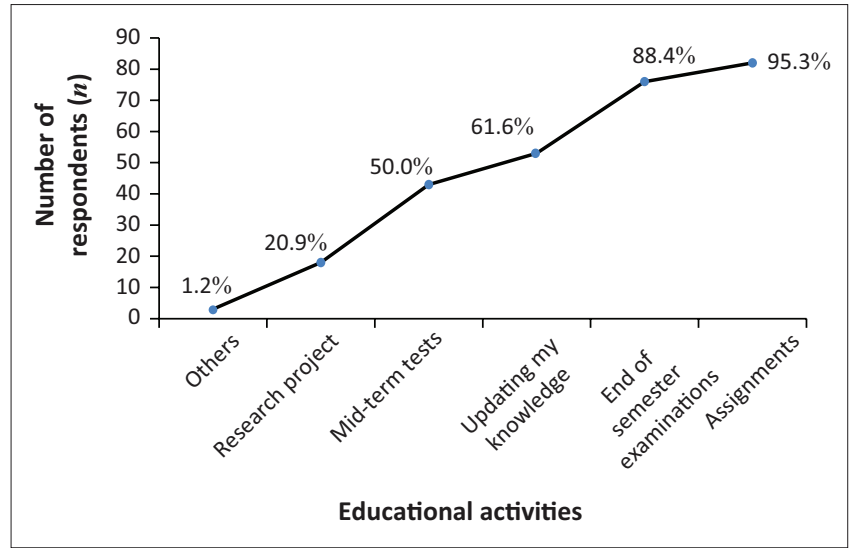

FIGURE 2: Kinds of educational activities $(n=86)$.
These results give credence to anecdotal evidence that the Internet is overtaking the library as a source of information for students. There is a need to assist students to use credible Internet sources for information in order to reduce the use of credible sources as highlighted by Karobilli et al. (2011). The presence of the Internet is also an indication that the Internet is slowly replacing the use of hard copy textbook as one can access the information on the phone or laptop without physically visiting the library.

Overreliance on the Internet as a source of information in this study may also be attributed to network infrastructure with free high-speed Internet to students at Mzuzu University (Chawinga 2017; Chawinga \& Zinn 2015, 2016; Chawinga \& Zozie 2016).

Considering that the majority of students used Internet as a source of information, we asked them to mention the places from which they accessed it. The findings revealed that $66(76.7 \%)$ students accessed the Internet via university computer laboratories, $63(73.3 \%)$ accessed it through their mobile phones, 42 (48.8\%) accessed it in the Mzuzu University Library Internet room, $16(18.6 \%)$ accessed from friends' phones and only $7(8.1 \%)$ students indicated that they accessed it in the Mzuzu University American Corner. Focus group discussions revealed that students' choices on where to access Internet were based on convenience from classes, speed of Internet and cost. Compared to the findings by Chawinga and Ngwira (2015), the use of the Mzuzu University American Corner as a source of Internet has drastically declined from $75 \%$ to $8.1 \%$. Thus, its decline in use by students is attributed to the introduction of many computer laboratories within the teaching area with highspeed Internet on Mzuzu University campus where students access Internet for free.

We asked students to indicate the information-seeking activities that they employ when starting an information search. Results presented in Table 1 show that the majority of students with scores of 76 (88.4\%), 50 (58.2\%) and $40(46.6 \%)$ search the Internet first, consult classmates and browse the library shelves, respectively. These results give credence to the findings discussed in the previous sections about the popularly of the Internet where we reported that the Internet was the most preferred source of information by students. Greenberg and Bar-llan (2014) also found that students in Israeli universities mostly used search engines as a source of information. Again, the use of the library by students as a source of information is proved low because, according to the findings presented in Table 1, less than half of the students accessed the library. Worse still, the number of students who consulted the library staff as a starting point for their information search is very small, that is, 16 (18.6\%). Given the linkage between their academic information search and work place, there may be a need to further explore this linkage. Therefore, there is a need to do further research to understand the security studies students' use of the Mzuzu University Library, the linkage between academic information and their 
TABLE 1: Information-seeking seeking strategies.

\begin{tabular}{|c|c|c|c|c|c|c|c|c|c|c|}
\hline \multirow[t]{2}{*}{ Information seeking strategies } & \multicolumn{2}{|c|}{ Very often } & \multicolumn{2}{|c|}{ Often } & \multicolumn{2}{|c|}{ Rarely } & \multicolumn{2}{|c|}{ Never } & \multicolumn{2}{|c|}{ Not sure } \\
\hline & $f$ & $\%$ & $f$ & $\%$ & $f$ & $\%$ & $f$ & $\%$ & $f$ & $\%$ \\
\hline Search engines & 64 & 74.4 & 12 & 14.0 & 0 & 0 & 0 & 0 & 0 & 0 \\
\hline Consult a classmate & 20 & 23.3 & 30 & 34.9 & 24 & 27.9 & 3 & 3.5 & 3 & 3.5 \\
\hline Shelf browsing (print books, journals) & 20 & 23.3 & 20 & 23.3 & 22 & 25.6 & 7 & 8.1 & 4 & 4.7 \\
\hline Consult a lecturer's recommended list & 20 & 23.3 & 19 & 22.1 & 23 & 26.7 & 7 & 8.1 & 7 & 8.1 \\
\hline Library's website e-journals database & 10 & 11.6 & 20 & 23.3 & 17 & 19.8 & 23 & 26.7 & 5 & 5.8 \\
\hline
\end{tabular}

work, and to devise strategies to boost its use. This is important because George, Bright and Hulbert (2006:1) advised that for a library to be able to provide better services meeting the needs of its users, there is a need to understand their information behaviours.

Kuhlthau's ISP model highlights that individuals usually develop some feelings when they embark on an information search. These feelings include uncertainty, anxiety, optimism, confusion, frustration, doubt and relief (Kuhlthau 1993:43). In the current study, we asked students to indicate if they experienced these feeling during an information search, and the results are summarised in Figure 3. The results show that the common feelings that most students develop include anxiety, optimism, uncertainty and excitement, with scores of $83(96.5 \%), 79(91.9 \%), 64(74.4 \%)$ and $63(73.3 \%)$, respectively. Results from FGDs showed that level 1 students developed confusion and doubt. The most interesting finding as presented in Figure 2 is that some students develop feelings that they will fail in an assignment. A further analysis of the results showed that the small number of students $(7 ; 8.1 \%)$ who indicated that they feel that they can fail in an assignment were from level 1 . The reason is that level 1 students are new in the university and are not very familiar with writing assignments and hence the feeling, whereas levels 2 and 3 students are used to search information for accomplishing their assignments. In fact, results from FGDs showed that students in level 1 were less experienced in searching for information to accomplish their academic activities. This agrees well with Chaura's (2014) study which found that senior students, especially those in level 3, are more likely to feel optimistic in passing an assignment because they (students) are accustomed to doing assignments.

The results therefore confirm some of Kuhlthau's ISP elements (anxiety, optimism, uncertainty, excitement, confusion and doubt) and fail to conform to other elements such as frustration and relief. We suggest that the fact that most students used Internet as a key source of information may have contributed to the reason some elements of the ISP did not affect students. After all, the ISP model was developed from a study that targeted students who used print-based materials in a typical traditional library (Kuhlthau 1993:43).

Students were also asked to indicate what they do when they fail to find information they need at the first attempt. A thematic analysis of the results showed that $84(97.7 \%)$ students changed search terms or keywords, 41 (47.7\%) students found out from friends and 36(41.9\%) students

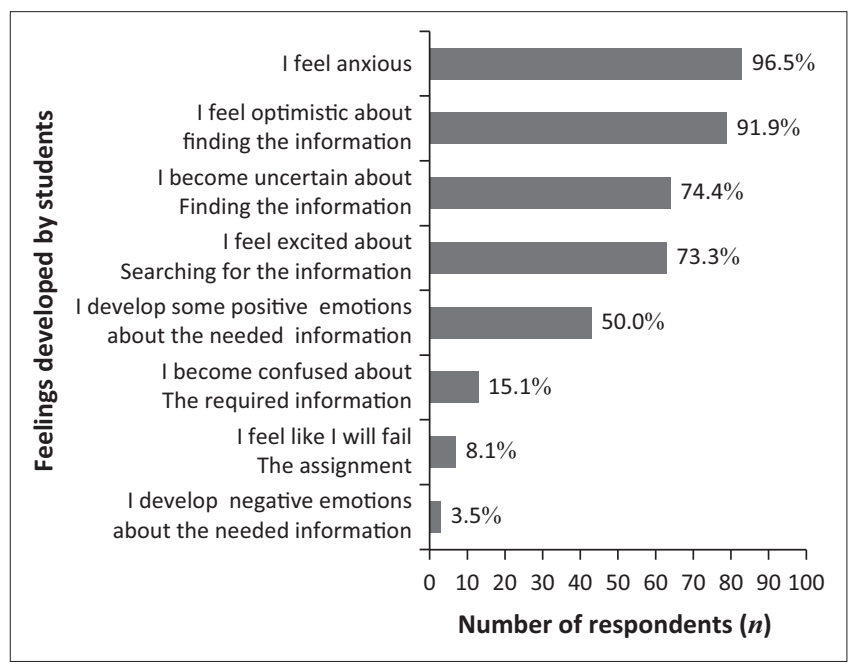

FIGURE 3: Feelings of students during information search $(n=86)$.

consulted their lecturers issuing a particular assignment and only $7(8.1 \%)$ students tried to look for such information at another library. The most interesting result is that no students mentioned that they 'do nothing'. This result is not surprising because every student would want to pass, hence their efforts to find alternatives in accessing information for accomplishing their assignments. In addition, this may also be attributed to upgrading security students', especially those from police and intelligence services, persistent nature of seeking information when discharging of their duties, no matter the obstacles they may encounter. Therefore, students' experience outside the academic work has influence on their information-seeking behaviour.

Interpreting these findings through the lens of the model informing this study, it is easy to understand why students have to explore other means after their first attempt to find the information is unsuccessful. According to the ISP Model, when users have knowledge gaps about a topic, they have to do all they can to find the information (Kuhlthau 1993:161).

According to the findings, students do not look for information from other libraries because of three key reasons. Firstly, Mzuzu University is the only university in Mzuzu City that offers academic-related information resources. Secondly, Mzuzu University is the only university offering security studies; hence, it is not easy to find such information at any other information centre in Malawi. Finally, students' preference of Internet as a source of information means that they do not see any reason for trying at other libraries. After all, according to the findings, only a small number of students 
use the Mzuzu University Library which is located right on the campus where these students reside.

\section{Challenges}

The last questionnaire item solicited students' views on the challenges they faced in their information-seeking activities. Results presented in Figure 4 show clearly that the challenges are Internet related, mainly because results presented in previous sections have showed that this group of students mostly use the Internet as a source of information. Lack of Internet search skills is the major problem, with a score of $78(90.7 \%)$, followed by confusion because of too much information on the Internet with a score of $71(82.6 \%)$ and, finally, the problem of poor Internet, with a score of $53(61.6 \%)$. The problem of poor Internet search skills and the information explosion are seen as related in this study. For instance, in all three FGDs, it was pointed out that the students face technological challenges, making it difficult to search and evaluate information. From these results, we conclude that students have poor online literacy skills; hence they are overwhelmed by the amount of information available on the Internet. Other researchers, such as Chawinga and Zozie (2016), expressed concern over students' lack of competency in searching and evaluating information available on the Internet. They (Chawinga \& Zozie 2016:9) worry that Internet is a complex and dynamic landscape full of all sorts of information and questions, and ideally, that students should possess ideal information literacy skills to distinguish between good and bad sources of information sourced from the Internet. However, these results are not exceptional to security studies students at Mzuzu University because Brindesi, Monopoli and Kapidakis (2013) also found that students at the University of Athens were not very good at evaluating online information and lacked information searching skills. Lack of online literacy skills seems to be a common problem amongst undergraduate students because Duncan and Holtslander (2012) equally found that students had problems in formulating appropriate keywords as search words or phrases. Students' failure to effectively find the right information can frustrate them, an element that is highlighted

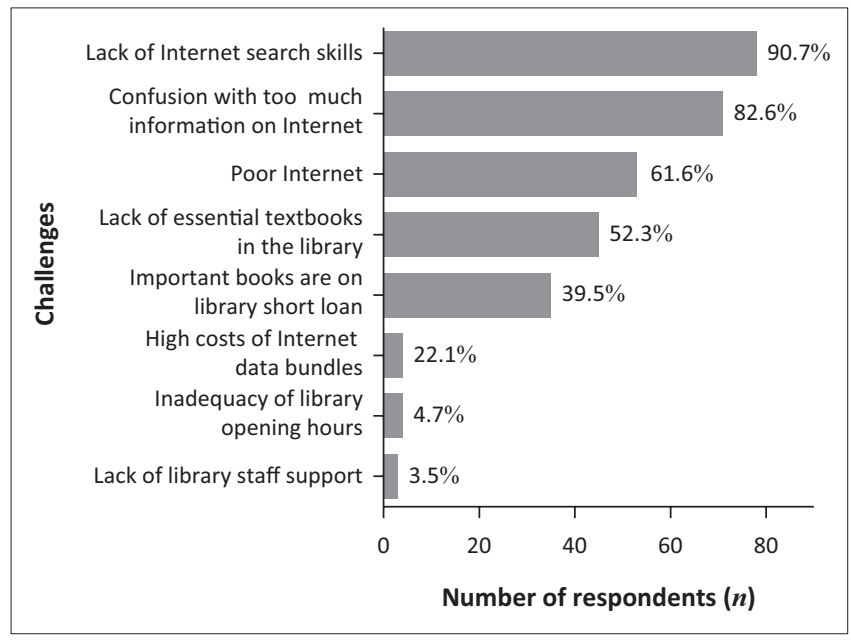

FIGURE 4: Challenges that students face in searching for information. by the ISP, a model informing this study. Nkomo et al. (2011:293) claim that if students are property trained, they will have little difficulties in searching credible scholarly websites which contain peer reviewed information.

This study also uncovered some challenges arising from the use of Internet resources. In all three the FGDs, students mentioned congestion in the university Internet laboratories, network problems and limited Wi-Fi. A participant from FGD 1 mentioned that 'usually, from 07:30 to 16:30, classes are in progress and when [we are] free after 16:30, ICT labs [computer laboratories] are closed, hence access is limited.' Worse still, these computer laboratories are not enough because participants from all the FGDs mentioned that these computer laboratories are mostly congested and the Internet becomes very slow and Wi-Fi is not reliable because the range of access points is restricted to a few places on the campus. As revealed during the FGD, for students who attempt to use the Internet in the library, they are equally met with convincing challenges, which include poor Internet connection, limited time given to each student to use the Internet, old computers and each student having allocated only $50 \mathrm{MB}$ of Internet data usage and the library becomes too congested when other computer laboratories are closed after 16:30. Based on these challenges, it can be argued that despite student preference of the Internet as a source of information, there is a need to address the aforementioned challenges so that the negative feelings highlighted by Kuhlthau's model are reduced and the Internet use achieves positive results. This calls for frequent refresher courses that orient students towards better use of the Internet. There is also a need to have competent library staff to support the students regarding the Internet use.

\section{Conclusion and recommendations}

The study has demonstrated that the Internet is the most popular form of information sources amongst undergraduate security studies students. The results also showed varying student feelings across the three levels. For instance, some level 1 students developed feelings or fears of failing an assignment. The study also confirmed four key feelings: anxiety, optimism, uncertainty and excitement, which were suggested by Kuhlthau's information processing model. The findings showed that students lack online information literacy skills and, consequently, they get overwhelmed and confused by the avalanche of information available on the Internet. The study established that apart from limited Wi-Fi and shortage of computer laboratories, poor Internet was another notable challenge. Unlike previous studies, this study established that information needs of upgrading security studies students are focussed more on academic and work-related activities. Information seeking and gathering is a key component of their work as they gather information related to criminal activities and general intelligence. Upgrading undergraduate students have additional information needs that go beyond their academic needs. There is a need to design information interventions that 
would enhance their information search experience based on some of the pointers provided by Kuhlthau's model.

In view of the above discussion, it can be argued that the Internet is becoming a popular source of information in the 21st century; hence, there is a need to provide e-support that would reduce students' negative feelings and enhance their Internet search process, thereby improving the quality of education.

The study makes three key recommendations. Firstly, the Centre for Security Studies should work hand in hand with the Mzuzu University Library and the Department of Information Science to introduce information literacy courses, with a major component on searching and evaluating online information resources. Finally, the Centre for Security Studies should set up a computer laboratory where students can access Internet instead of going to other laboratories on the campus. The library should consider expanding its computer laboratories to reduce congestions. Finally, Mzuzu University should consider extending opening hours for computer laboratories so that students can have access to them for longer periods of the day.

\section{Acknowledgements Competing interests}

The authors declare that they have no financial or personal relationships which may have inappropriately influenced them in writing this article.

\section{Author's contributions}

T.T. conceptualised the project, collected the data and was involved in the overall writing of the article. W.D.C. and G.D. analysed the data and discussed the findings and were responsible for addressing reviewers' comments and concerns.

\section{References}

Abrahamson, D.E. \& Goodman-Delahunty, J., 2014, 'Impediments to information and knowledge sharing within policing: A study of three Canadian policing organizations', Sage Open 4(1), 1-17. https://doi.org/10.1177/2158244013519363

Adio, G. \& Arinola, A.A., 2012, 'Information needs and information-seeking behavior of agricultural students', PNLA Quarterly 76(3), 13-39. https://doi.org/10.1016/ S0740-8188(99)00051-1

Ajiboye, J.O. \& Tella, A., 2007, 'University undergraduate students' information seeking behaviour: Implications for quality in higher education in Africa', The Turkish Online Journal of Educational Technology-TOGET 6(1), 40-52.

Baro, E.E., Onyenania, G.O. \& Osaheni, O., 2010, 'Information seeking behaviour of undergraduate students in humanities in three universities in Nigeria', South African Journal of Library \& Information Science 76(2), 109-117. https:// doi.org/10.7553/76-2-74

Bhatti, R., 2008, 'Information needs of students-Islamia University Library, Bahawalpur', Pakistan Library \& Information Science Journal 39(3), 6-21.

Braun, V. \& Clarke, V., 2006, 'Using thematic analysis in psychology', Qualitative Research in Psychology 3(2), 77-101.

Brindesi, H., Monopol, M. \& Kapidakis, S., 2013, 'Information seeking and searching habits of Greek physicists and astronomers: A case study of undergraduate students', Proceedings in Social and Behavioural Sciences 73(2013), 785-793. https://doi.org/10.1016/j.sbspro.2013.02.119

Byström, K. \& Jarvelin, K., 1995, 'Task complexity affects information seeking and use', Information Seeking and Management 31(2), 191-213. https://doi.org/10.1016/ 0306-4573(95)80035-R
Chaura, M.G., 2014, 'Information behaviour of fourth year students of Mzuzu University in Malawi', Library Philosophy and Practice (e-journal), viewed 11 May, 2018, from https://search.proquest.com/openview/2dc385c14771cd320c808a88 2018, from https://search. proquest.com/open
fb5b2eeb/1?pq-origsite=gscholar\&cbl=54903

Chawinga, W.D., 2017, 'Taking social media to a university classroom: Teaching and learning using Twitter and blogs', International Journal of Educational Technology in Higher Education 14(3), 1-19. https://doi.org/10.1186/s41239-017-0041-6

Chawinga, W.D. \& Ngwira, F., 2015, 'The role of the Mzuzu American Corner Information Technology and Communication Centre, Malawi', Innovation: Journal of Appropriate Librarianship and Information Work in Southern Africa 50, 20-43, viewed 06 June, 2018, from http://reference.sabinet.co.za/document/EJC174762

Chawinga, W.D. \& Zinn, S., 2015, 'Lecturers' use of Web 2.0 in the Faculty of Information Science and Communications at Mzuzu University, Malawi', Mousaion: South African Journal of Information Studies 33(4), 62-85, viewed 10 June, 2018, from http://www.upjournals.co.za/index.php/LIS/article/view/699.

Chawinga, W.D. \& Zinn, S., 2016, 'Use of Web 2.0 by students in the Faculty of Information Science and Communications at Mzuzu University, Malawi', South African Journal of Information Management 18(1), a694. https://doi.org/ 10.4102/sajim.v18i1.694

Chawinga, W.D. \& Zozie, P.A., 2016, 'Information needs and barriers to information sources by open and distance learners: A case of Mzuzu University, Malawi', South African Journal of Information Management 18(1), 1-12.

Duncan, V. \& Holtslander, L., 2012, 'Utilizing grounded theory to explore the information-seeking behaviour of senior nursing students', Journal of the Medical Library Association 100(1), 20-27. https://doi.org/10.3163/1536-5050.100.1.005

Etikan, I., Musa, S.A. \& Alkassim, R.S., 2016, 'Comparison of convenience sampling and purposive sampling', American Journal of Theoretical and Applied Statistics 5(1), 1-4. https://doi.org/10.11648/j.ajtas.20160501.11

Ferran-Ferrer, N., Minguillon, M.P. \& Perez, M., 2013, 'Key factors in the transfer of information-related competencies between academic, workplace, and daily life contexts', Journal of the American Society for Information Science and Technology 64(6), 1112-1121. https://doi.org/10.1002/asi.22817

George, C., Bright, A. \& Hulbert, T., 2006, 'Scholarly use of information: Graduate students' information seeking behaviour', Information Research 11(4), 1-23.

Greenberg, R. \& Bar-llan, J., 2014, 'Information needs of students in Israel - A case study of a multicultural society', The Journal of Academic Librarianship 40(2), 185-191. https://doi.org/10.1016/j.acalib.2013.10.002

Guclu, I. \& Can, A., 2015, 'The effect of socio-demographic characteristics on the information-seeking behaviors of police officers', Policing: An International Journal of Police Strategies \& Management 38(2), 350-365. https://doi.org/ 10.1108/PIJPSM-12-2014-0132

Ikoja-Odongo, R. \& Mostert, J., 2006, 'Information seeking behavior: A conceptual framework', South African Journal of Library \& Information Science 72(3), 145-158. framework', South African Journal of
https://doi.org/10.7553/72-3-1112

Hildegard, J., 2006, 'Collaborative information behaviour-exploring Kuhlthau's Search Process Model in a group-based educational setting', Information Processing and Management 42(1), 276-298. https://doi.org/10.1016/j.ipm.2004.06.013

Kakai, M., Ikoja-Odongo, R. \& Kigonga-Bukenya, I., 2004, 'A study of the information seeking behaviour of undergraduate students of Makerere University, Uganda', World Libraries 14(1), 1-22.

Karas, M. \& Green, R., 2007, 'The information needs and information-seeking behaviors of community college and lower division undergraduate students', Community \& Junior College Libraries 14(2), 103-109. https://doi.org/10.1300/ 02763910802139199

Khalil-Malik, S.A. \& Azhar, M.N., 2011, 'Information seeking behavior of undergraduate medical students. A case study', Pakistan Library Information Science Journa 42(4), 41-60. https://doi.org/10.2196/mededu.4267

Karobilli, S., Mallards, A. \& Zapounidou, S., 2011, 'Factors that influence informationseeking behaviour: The case of Greek graduate students', The Journal of Academic Librarianship 37(2), 155-165. https://doi.org/10.1016/j.acalib.2011.02.008

Krikelas, J., 1983, 'Information-seeking behaviour: Patterns and concepts', Drexel Library Quarterly 19(2), 5-20.

Kuhlthau, C.C., Heinstrom, J. \& Todd, R.J., 2008, 'The ISP revisited: Is the model still useful?', Information Research 13(4), 4-13.

Kuhlthau, C.C., 1993, Seeking meaning: A process approach to library and information services, Ablex, Westport, CT.

Kuhlthau, C., Maniotes, L. \& Caspari, A., 2012, Guided inquiry design: A framework for inquiry in your school, Libraries Unlimited, California.

Kurniawan, S., Mahmud, M. \& Nugroho, Y., 2006, 'A study of the use of mobile phones by older persons', in Association of Computing Machinery (ed.), $\mathrm{CHI}$ ' 06 : $\mathrm{CHI}$ 'O6 Extended Abstracts on Human Factors in Computing Systems, pp. 989-994, Association of Computing Machinery, Montréal, QC.

Kundu, K., 2017, 'Models of information seeking behaviour: A comparative study', International Journal of Library \& Information Studies 7(4), 393-405, viewed n.d., from http://ijlis.org/img/2017_Vol_7_Issue_4/393-405.pdf

Lester, F.K., 2005, 'On the theoretical frameworks, conceptual and philosophical foundations for research in mathematics education', International Reviews on Mathematical Education 37(6), 457-467.

Mizrachi, D. \& Bates, M.J., 2013, 'Undergraduates' personal academic information management and consideration of time and task-urgency', Journal of the American Society for Information Science and Technology 64(8), 1590-1607. https://doi.org/10.1002/asi.22849

Morgan, D.L., 1997, The focus group guidebook, Sage, London

Muijs, D., 2010, Doing quantitative research in education with SPSS, Sage, London. 
Nkomo, N., Ocholla, D. \& Jacobs, D., 2011, 'Web information seeking behaviour of students and staff in rural and urban based universities in South Africa', Libri 61(4), 281-297. https://doi.org/10.1515/libr.2011.024

Nwobasi, R.N., Uwa, E.O. \& Ossai-Onah, O.V., 2013, 'Information needs and seeking behaviour of students in two universities in Imo State, Nigeria', Library Philosophy and Practice (e-journal), viewed 11 July, 2018, from http://digitalcommons.unl. edu/libphil

Oladokun, O.S. \& Aina, L.O., 2009, 'Library and information needs and barriers to the use of information sources by continuing education students at the University of Botswana', Library Development 25(43), 43-50. https://doi.org/10.1177/02666 66908101263

Punch, K.F., 1998, Introduction to social research qualitative and quantitative approaches, Sage, London.

Saad, M.S.M. \& Zainab, A.N., 2009, 'An investigation of information seeking behavior of computer science and information technology undergraduate: A qualitative approach', Malaysian Journal of Library \& Information Science 14(3), 15-34.

Savolainen, R., 2007, 'Information behavior and information practice: Reviewing the "Umbrella concepts" of information seeking studies', Library Quarterly 77(2), 109-132. https://doi.org/10.1086/517840

Shyu, H. \& Pern, K., 2013, 'The comparison study of factors influencing information behaviors between undergraduate students and teachers in university', Journal of Educational Media \& Library Science 50(3), 393-423.
Singh, N. \& Rani, M., 2013, 'Information seeking behaviour of faculty of Chitkara University (Punjab): A case study', International Journal of Information Dissemination and Technology 3(2), 94-98.

Sookhtanlo, M., Mohammadi, H.M. \& Rezvanfar, A., 2009, 'Library Informationseeking behavior among undergraduate students of agricultural extension and education in Iran', DESIDOC Journal of Library \& Information Technology 29(4), 12-20. https://doi.org/10.14429/djlit.29.4.256

Tella, A., 2009, 'Correlates of undergraduates' information-seeking behavior', College and Undergraduate Libraries 16(1), 1-19. https://doi.org/10.1080/10691310 902754221

Vezzosi, M., 2009, 'Doctoral students' information behaviour: An exploratory study at the University of Parma (Italy)', New Library World 110(1/2), 65-80. https://doi. org/10.1108/03074800910928595

Whitmire, E., 2001, 'Undergraduates' background characteristics and college experiences and their academic library use', College \& Research Libraries 62(6), 528-540.

Wilson, T.D., 1981, 'On user studies and information needs', Journal of Documentation 37(1), 3-1. https://doi.org/10.1108/eb026702

Wilson, T.D., 1999, 'Models in information behaviour research', Journal of Documentation 55(3), 249-270.

Wilson, T.D., 2000, 'Human information behavior', Special Issue on Information Science Research 3(2), 49-55. 